
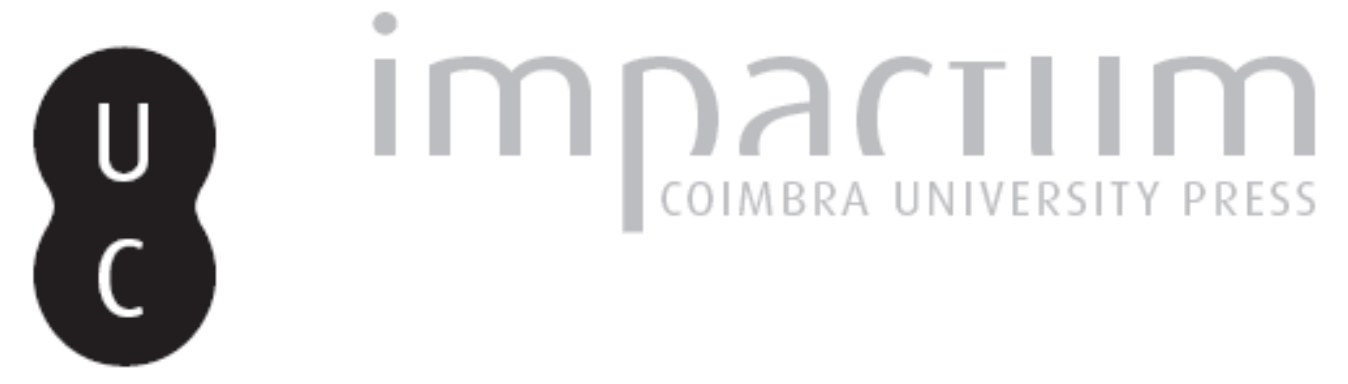

\title{
The Dyschereis of the Magna Moralia
}

\section{Autor(es): $\quad$ Tarrant, Harold}

Publicado por: Imprensa da Universidade de Coimbra

URL persistente:

URI:http://hdl.handle.net/10316.2/42208

DOI:

DOl:https://doi.org/10.14195/2183-4105_8_2

Accessed : $\quad$ 26-Apr-2023 10:52:22

A navegação consulta e descarregamento dos títulos inseridos nas Bibliotecas Digitais UC Digitalis, UC Pombalina e UC Impactum, pressupõem a aceitação plena e sem reservas dos Termos e Condições de Uso destas Bibliotecas Digitais, disponíveis em https://digitalis.uc.pt/pt-pt/termos.

Conforme exposto nos referidos Termos e Condições de Uso, o descarregamento de títulos de acesso restrito requer uma licença válida de autorização devendo o utilizador aceder ao(s) documento(s) a partir de um endereço de IP da instituição detentora da supramencionada licença.

Ao utilizador é apenas permitido o descarregamento para uso pessoal, pelo que o emprego do(s) título(s) descarregado(s) para outro fim, designadamente comercial, carece de autorização do respetivo autor ou editor da obra.

Na medida em que todas as obras da UC Digitalis se encontram protegidas pelo Código do Direito de Autor e Direitos Conexos e demais legislação aplicável, toda a cópia, parcial ou total, deste documento, nos casos em que é legalmente admitida, deverá conter ou fazer-se acompanhar por este aviso. 


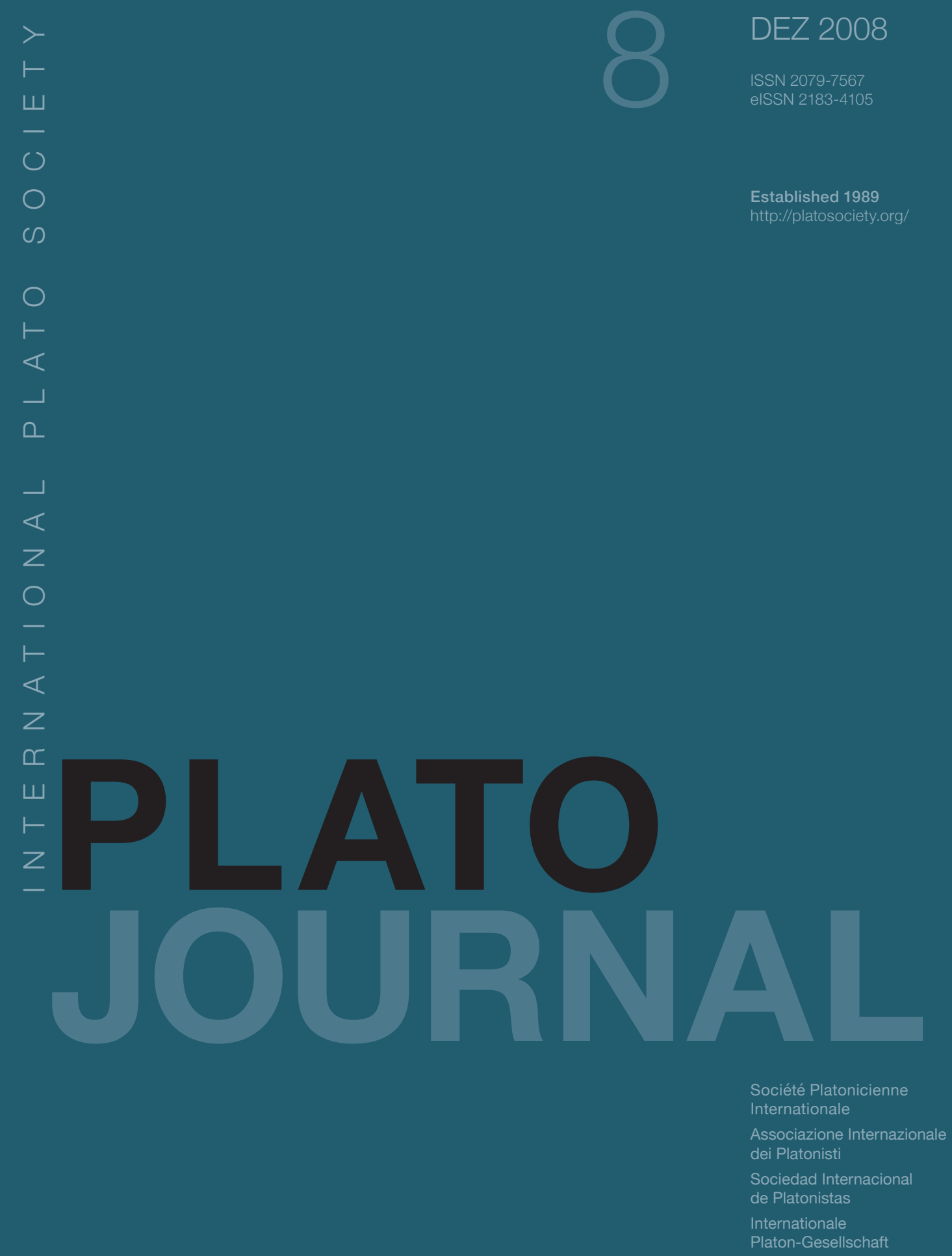




\section{THE DYSCHEREIS OF THE MAGNA MORALIA}

\section{i. Introduction}

The identity of the 'enemies of Philebus' at Philebus 44b-51a, known as the dyschereis thanks to the prominence of this adjective and of some striking related terminology, ${ }^{1}$ has long been a matter of controversy. If we aim only to understand Plato himself, then it is arguable that the question does not require settling. But it is important for those wishing to understand some of the fragmentary thinkers (most notably Speusippus and Heraclides Ponticus), ${ }^{2}$ with whom the dyschereis could plausibly be identified. Those who deal with these authors must decide whether Plato's passage may be used as supplementary evidence for their moral

1 Terms first occur as a cluster at $44 \mathrm{c} 6, \mathrm{~d} 2, \mathrm{~d} 8$, and e4, and Plato is conscious that he has invented a name by using this adjective (46a5). But the meaning of the name is not easily

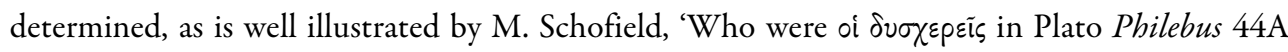
ff?', $M H 28$ (1971), 2-20, who concludes that Plato is challenging us to think carefully about what he is doing here. An adjective that would normally seem to have meant by this time 'problematic' or 'objectionable', seems to be applied in the active sense to those given to raising problems or objections. It should not be forgotten, though, that before one meets the adjective one encounters

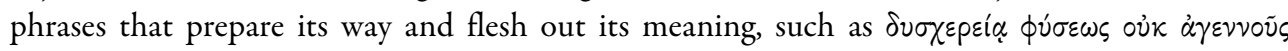
(44c6).

2 The plausibility of seeing the passage as an oblique reference to the views of Speusippus, the popular thesis most eloquently defended by Schofield (above, n.1), is defended against L. Tarán, Speusippus of Athens (Leiden 1981), 78-85, by John Dillon, 'Speusippe et le plaisir', in M. Dixsaut, F. Teisserenc (eds), La Fêlure du Plaisir, Paris 1999, 83-98; cf. id. The Heirs of Plato (Oxford 2003), 67-76. K. Bringmann, 'Platons Philebos und Herakleides Ponticus' Dialog $\pi \varepsilon p i$

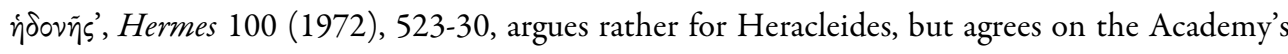
relevance to the Philebus (526). Nor would it undermine the argument for Speusippus, the first Academic that Heraclides attached himself to (DL $5.86=\mathrm{fr} .3 \mathrm{Wehrli}$ ). However, it is strange to link the dyschereis with a dialogue in comic mode (fr. 52) that was a favourite of Athenaeus (frs 55-69, 71); for the weaknesses of Bringmann's case see A. Brancacci, 'Le $\pi \varepsilon p i$ iं $\delta 0 v \tilde{\eta} s$ d'Héraclide du Pont (fr. 55 Wehrli), in Dixsaut and Teisserenc (above), 99-125.

PLATO, The electronic Journal of the International Plato Society, n 8, 2008.

http://gramata.univ-paris1.fr/Plato

(c) All rights of reproduction of any form reserved. 
philosophy. They need to establish the identity of these 'enemies of Philebus', but they are impeded by the teasing or ironic tones of the Platonic passage. They may share some of the puzzlement of Protarchus at 44b4-5, b8, c3-4, and $45 \mathrm{~d} 1$, for it is clear that Plato's aim here is something other than an informative picture of an anti-hedonist's position, and so, whoever he has in mind, we may struggle to reconcile his account with the testimony of others who do wish be informative but have fewer facts at their disposal. A further obstacle is that Aristotle, where he attaches Speusippus' name to an argument on pleasure, does not set it in a wider context.

I here examine only a preliminary question that ought to be raised in relation to Plato's dyschereis, namely whether they are to be identified with the antihedonists of the Aristotelian Magna Moralia $(2.7),{ }^{3}$ henceforth abbreviated MM. While the $M M$ is certainly not discussing philosophers who have difficulty talking about pleasure, and the Philebus discusses those for whom pleasures as ordinarily conceived simply do not exist, this must not discourage our investigation. For it is absurd that any anti-hedonists should abolish the word 'pleasure' from their philosophic discourse. Even the enemies of Philebus apparently recognise the power of pleasure (44c7) and its seductive nature (c8), seeing it as a form ( $\left.\varepsilon^{\tilde{\delta} \delta} \circ \varsigma, \mathrm{e} 1\right)$ or type ( $\left.\gamma^{\varepsilon} v \circ \varsigma, \mathrm{e} 7\right)$ of some kind, and affording it a nature of its own ( $\phi \dot{v} \sigma \mathrm{s}$, e8). The paradox emerges at Philebus 45c8:

We are saying that we should understand what nature it has, and what is meant by those who claim that it does not even exist at all.

\footnotetext{
3 The authorship and date of this work is something that does not need to be tackled at this point (for my hope is rather that my conclusions might help others throw a little light on the question), but it is important that it relates closely to the Eudemian Ethics in general, while this section relates to the 'common book' discussion of pleasure at Nicomachean Ethics book VII.1114 (now most commonly seen as 'Eudemian') more closely than to the book X discussion.
}

PLATO, The electronic Journal of the International Plato Society, n 8, 2008. http://gramata.univ-paris1.fr/Plato

(c) All rights of reproduction of any form reserved. 
The meaning of the enemies of Philebus is not self-evident, and requires interpretation. The denial of 'existence' appears to be linked with a view of the nature of pleasure, for these people are introduced as experts on nature (44b9). It is at this stage important to note only that Plato's dyschereis have no difficulty in theorising about pleasure. So if the dyschereis of the $M M$ have no difficulty with this either, then this is no reason for refusing to consider their identity.

\section{ii. The other dyschereis introduced}

The anti-hedonists of the $M M$, for whom the plural is consistently used once again, collected various anti-hedonist arguments. ${ }^{4}$ We should pay particular attention to the way in which they are introduced at 2.7.1:

1. Most obviously, the text uses the participle-phrase $\tau \tilde{\eta} \dot{\eta} \delta 0 v \tilde{\eta}$

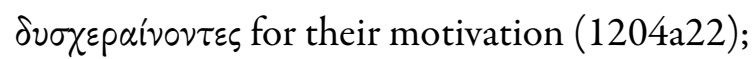

2. their difficulties cause them to deny that pleasure is to be classed as a good;

3. their denial is first seen as a refusal to allow that pleasure should be numbered among ( $\dot{\varepsilon} \nu \alpha \rho \theta \mu \varepsilon \tilde{\sigma} \sigma \alpha \mathrm{l})$ good things;

4. it is secondly (2.7.3) seen as a claim that pleasure does not belong in the

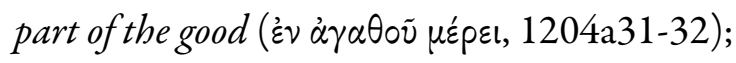

5. they thus allow only that freedom from pain may be an ingredient of happiness.

While the use of the suggestive verb $\delta v \sigma \varepsilon$ paiv the Philebus or guarantee that these people are Plato's dyschereis, to begin with their attitudes to pleasure rather than their philosophic position requires some special reason. Most anti-hedonists 'have problems with' or 'object to' pleasure in some sense. So has the language once used by the Philebus acquired special

$4 \quad$ There is much overlap with EN 7.11 (1152b12-20).

PLATO, The electronic Journal of the International Plato Society, n 8, 2008. http://gramata.univ-paris1.fr/Plato

(c) All rights of reproduction of any form reserved. 
significance in discussions of pleasure? One notes that the adjective is associated by Aristotle with an attack on unseemly pleasures at EN 1176a20: 'It is in no way remarkable that things objectionable to this person ( $\tau \dot{\alpha} \tau 0 v \dot{\tau} \omega \delta \nu \sigma \chi \varepsilon p \tilde{\eta}$, referring to the man of virtue) should seem pleasant to somebody.' The word might be significant here too, for I find only two more uses in the Nicomachean Ethics $(1145 \mathrm{~b} 6,1166 \mathrm{~b} 15)$. Furthermore, there was a particular kind of unseemly physical pleasure, like scratching an itch, that the enemies of Philebus found detestable. Aristotle now specifies that the pleasures that he is talking of are associated with a debased nature, that they are not pleasant in themselves, only to certain individuals, and that 'it is clear that those which are acknowledged to be base ought not to be admitted to be 'pleasures', except to the corrupt.' So Aristotle is sneering at the same kind of pleasures as Plato's dyschereis, and he is suggesting that this kind of 'pleasure' is, just as they claim, not a real pleasure at all.

More important are linguistic details that describe how these anti-hedonists deny that pleasure is a good, or that it is an ingredient of happiness. Linguistic similarities may occur for a number of reasons, and may often be explained by various hypotheses. But, while they may be found to be individually convincing, they may nevertheless combine to make up as solid a case as this kind of question permits. On point three above, our anti-hedonists employ language of numbering and of classification that is distinctly reminiscent of the wider Philebus, where the science of classification as presented at 16c-19a relies on establishing some number of species in between a generic term and the seemingly unlimited

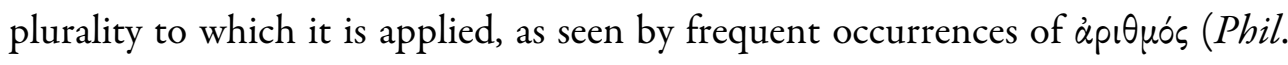

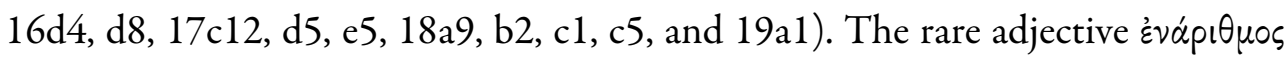
is encountered at $17 \mathrm{e} 5$, though the particular compound of $\dot{\alpha} \rho \theta \mu \varepsilon i \nu$ that one associates with the Philebus is rather $\kappa \alpha \tau \alpha p 1 \theta \mu \varepsilon \tau$, found at $27 \mathrm{~b} 5,47 \mathrm{~b} 7$, and $56 \mathrm{~d} 10$ and only four times elsewhere in Plato. ${ }^{5}$ The second case of this verb occurs during the section with which we are primarily concerned, and is used of the

Grg. 451e2, Symp. 215a3, Sph. 266e3, Plt. $266 \mathrm{a} 3$.

PLATO, The electronic Journal of the International Plato Society, n 8, 2008. http://gramata.univ-paris1.fr/Plato

(c) All rights of reproduction of any form reserved. 
dissolute character who 'counts most happy' those who are occupied most consistently with dissolute pleasures. Plt. 266a3 affords us with an example of this verb used in close proximity with $\dot{\varepsilon} \nu$ in a classificatory context, so that the rare term $\dot{\varepsilon} \alpha_{p} \theta \theta \mu \varepsilon \tilde{\sigma} \sigma \theta \alpha \mathrm{l}$ in the $M M$ is reminiscent of the world of the Philebus and of late Platonic discussion of classification. It is slightly more reminiscent of Speusippus F8 (Tarán), where $\kappa \alpha \tau \alpha p 1 \theta \mu \varepsilon i \sigma \theta \alpha \iota . . . \dot{\varepsilon} \nu$ is found in an isolated fragment of his great classificatory work Similars. It seems likely that the author or source of $M M$ consciously adopted his opponents' characteristic vocabulary, a vocabulary associated with the Academy at the time when Plato wrote the Philebus.

On point 4 above, we observe something similar. For $\dot{\varepsilon} \nu \dot{\alpha} \gamma \alpha \theta_{0} \tilde{v} \mu \varepsilon \dot{p} \rho \varepsilon$ at 1204a3132 is a prosaic variant on $\dot{\varepsilon} \nu \dot{\alpha} \gamma \alpha \theta_{0} \tilde{\nu} \mu$ poipa. It is thus reminiscent of Pbilebus

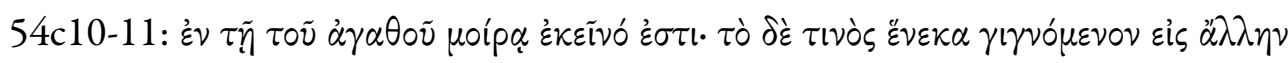

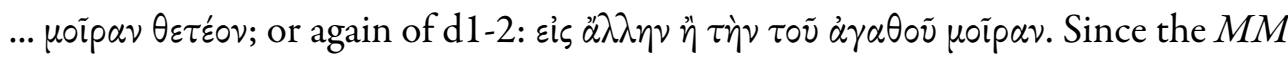
is here introducing the argument from pleasure as a genesis, which Plato explains at 54c-d, the resemblance is probably not fortuitous. It is unlikely that the author is here imitating Plato, but rather that he and Plato both capture the authentic language of these anti-hedonists. In fact, if one refers again to the same fragment of Similars one finds Speusippus following his use of $\kappa \alpha \tau \alpha p \imath \theta \mu \varepsilon \tilde{\sigma} \sigma \theta \alpha \mathrm{l}$ with an alternative: $\dot{\varepsilon} \nu \dot{\alpha} \lambda \lambda \omega \mu$ śp $\varepsilon^{2}$. The majority of Speusippean scholars who accept for him the fourth chapter of Iamblichus' partially derivative de communi mathematicae scientia ${ }^{6}$ would note that this too preserves similar language when

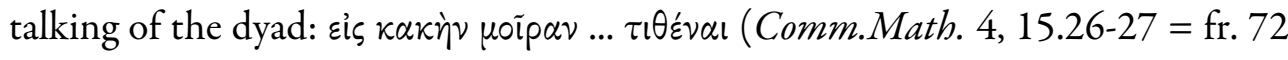
I-P). The term $\mu$ oipa is not Iamblichan, and occurs only in chapter $4 .{ }^{7}$ So the distinctive language used by the $M M$ when introducing those who refuse to

\footnotetext{
$6 \quad$ While L. Tarán excludes it, Speusippus of Athens (Leiden, 1981), 86-107, M. Isnardi Parente, Speusippo Frammenti (Naples, 1981), prints it as frs. 72 and 88.

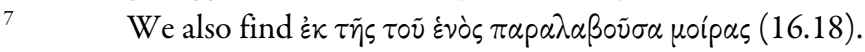

PLATO, The electronic Journal of the International Plato Society, n 8, 2008. http://gramata.univ-paris1.fr/Plato

(c) All rights of reproduction of any form reserved. 
regard pleasure as a good is reminiscent of language used by both Plato and his nephew in classificatory contexts.

Finally we come to point 5. Freedom from pain, unlike pleasure, is reckoned among things that are good by these anti-hedonists. It may not be the sole good, and indeed the Carneadea divisio in various Ciceronian works seems to have made nobody prior to the third century Hieronymous of Rhodes champion of the view that freedom from pain is the primary goal. ${ }^{8}$ But the author of $M M$ is so confident about these anti-hedonists seeing it as a factor in happiness that he now observes, perhaps with a hint of malice, that living without pain is not far away from living pleasantly.' As for Plato's 'enemies of Philebus' they maintain at $44 \mathrm{~b} 2-3$ that the release from pain is itself a good ( $\alpha \dot{v} \tau \dot{0} \tau \circ \tilde{v} \tau 0 \dot{\alpha} \gamma \alpha \theta \dot{o} v$ oैv) and is said to be 'pleasant' (by people discussed at 43d7-44a10). This back-reference confirms that we are dealing with a theory where the condition of having-beenreleased from pain is what is desirable, not the release itself. For the people concerned claimed that the pleasantest thing is to continue leading one's entire life

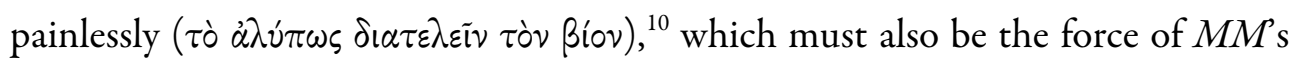
elliptical $\tau \dot{\alpha} \dot{\alpha} \lambda \dot{u} \pi \omega \varsigma$ at $1204 a 24$. Not only do Philebus' enemies see life without pain as good per se, they also see it as the pleasantest life achievable, so that the $M M$ is correct in claiming that their 'pain-free condition' is close to pleasure. If these persons pursue the pain-free life because it is the pleasantest available, then they legitimise pleasure (or pleasant-ness) as an object of pursuit.

There is thus a strong argument for believing that by using the verb $\delta v \sigma \chi \varepsilon p \alpha i v \omega$ the $M M$ alludes to the anti-hedonists to whom Plato applies the term $\delta v \sigma \chi \varepsilon p \varepsilon \varsigma_{\text {s. }}$ They have been introduced so as to reflect the language of the Philebus (and

\footnotetext{
$8 \quad$ See Cic. Fin. 2.8, 16, 19, 35, 41, 4.49, 5.14, 20, 73; Acad. 2.131.

9 To claim that the pain-free condition is close to pleasure denies the anti-hedonists any moral high ground, perhaps rightly.

$1043 \mathrm{~d} 8$, interpreted by Protarchus as 'Not to feel pain is pleasant'.
}

PLATO, The electronic Journal of the International Plato Society, n 8, 2008. http://gramata.univ-paris1.fr/Plato

(c) All rights of reproduction of any form reserved. 
perhaps of Speusippus) in other ways too, and their position on what can be counted as a good and as an ingredient of happiness coincides with that of the enemies of Philebus.

\section{iii. The Debate in the Magna Moralia}

In the remainder of 2.7.3 the $M M$ lists the arguments that the anti-hedonists employ, and in 2.7.4 it answers these arguments. The arguments are as follows:

1. Pleasure is a genesis, and a genesis is something incomplete; but the

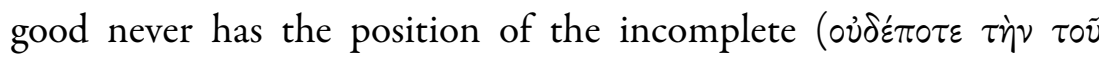
$\dot{\alpha} \tau \varepsilon \lambda \circ \tilde{\omega} \varsigma \chi \omega^{\prime} \rho \alpha \nu$ है $\left.\chi \varepsilon เ \nu\right) .{ }^{11}$

2. There are base pleasures, whereas the good is never found in baseness

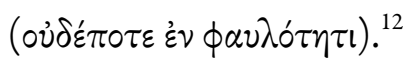

3. Pleasure occurs in all creatures (worthless and worthwhile men, wild and domesticated animals). But the good does not mix with the worthless, and is not common to many things. ${ }^{13}$

[3b: lacuna; 3c: pleasure is not best, but the good is best. $]^{14}$

4. Pleasure stands in the way of fine deeds, and what hinders fine deeds could not be good.

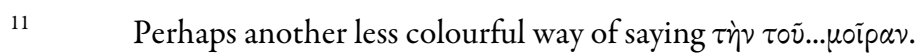

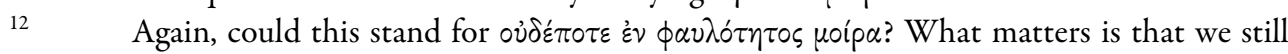
have here in $\dot{\varepsilon} v$ the language of classification as employed in the Philebus; e.g. it is especially fond

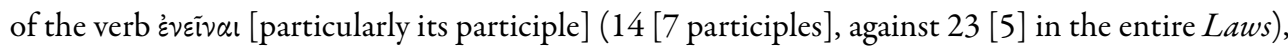

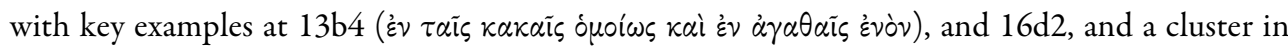
the 23c classification (at 24b5, c3, d2, d4, 26b9, 29a11, b6, 30b1).

13 Reminiscent of Speusippus (F83 = 71 I-P) in Theophrastus Met. 11a18-26, where Plato's nephew is associated with the view that the good is something scarce ( $\sigma \pi \dot{\alpha} \nu$ เóv $\tau \iota)$. The fragment should not be understood cosmologically, but as metaphysics underlying the ethics.

14 Spengel supplemented the text at $3 \mathrm{~b}$ noting that the reply covers also an argument that there is no craft of pleasure, whereas every good is the work of some skill (an argument occurring at $E N 7.11,1152 \mathrm{~b} 18-19)$; I suspect that both this and 3c were not independent arguments, but supplementary to 3 .

PLATO, The electronic Journal of the International Plato Society, n 8, 2008.

http://gramata.univ-paris1.fr/Plato

(c) All rights of reproduction of any form reserved. 
This collection of arguments is close to that of $E N 7.11$, but with significant variations. ${ }^{15} \mathrm{~W}$ ith the possible exception of $3 \mathrm{c}$, whose independent status may be questioned, all are concerned with classifying pleasure and 'good' in such a way that pleasure must occur in a different classificatory space from good. Of its very nature 'good' may never be predicated of pleasure. The centrality of classification, something that fails to emerge from the list of arguments at EN 7.11, will call to mind three Platonic dialogues in particular, Sophist, Statesman, and Philebus; and it should also recall the importance of classification to Speusippus' endeavours. ${ }^{16}$ $M M$ once again captures something characteristic of the anti-hedonists concerned, as it did by the language used to introduce them; and again we see that what it captures supports a close link with the Philebus.

Further clues occur during the ensuing refutation of individual arguments, beginning with the argument that pleasure is a genesis. The $M M$ associates this argument with the view that pleasure is always the correction of some painful lack or painful excess, involving a process of replenishment or correction, with the result that a painful lack would always precede the pleasure (2.7.4-6). At 2.7.10 we learn that the anti-hedonists call pleasure a perceived realignment with (one's)

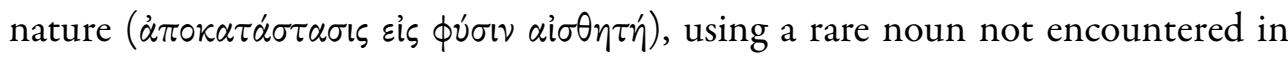
comparable passages, ${ }^{17}$ but belonging with this theory since EN1152b13 does

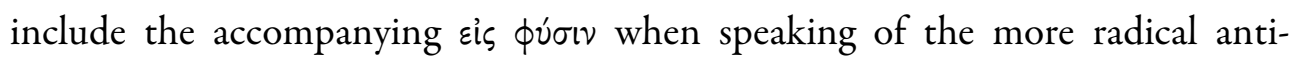
hedonist use of the argument (as opposed to its milder use at 1152b22-23). The noun is scientific language, so that the anti-hedonism is underpinned by scientific

15 See here J.C.B. Gosling and C.C.W. Taylor, The Greeks on Pleasure (Oxford 1982), appendix.

16 T33 and F6-F27 (Tarán).

17 This term, encountered twice in 2.7.10 and twice in 2.7.16 is otherwise absent from the Corpus Aristotelicum and from Plato (found in the spurious Axiochus). The only relatively early author to apply it to a restoration within the individual human is Aristoxenus (fr. 30.3 and 15 if correctly attributed). Here it refers to the Pythagorean practice of recovering equanimity before offering chastisement. The verb, found twice in 2.7.10, is found in both biological and astronomical contexts in Eudoxus, Aristotle, and Theophrastus.

PLATO, The electronic Journal of the International Plato Society, n 8, 2008.

http://gramata.univ-paris1.fr/Plato

(c) All rights of reproduction of any form reserved. 
inquiry into the biological nature of pleasure. The word for nature ( $\phi \dot{\sigma} \sigma \varsigma$ ) occurs 18 times in 68 lines at 2.7.10-18. ${ }^{18}$ Already at 44 a10 Plato used this word when switching to the enemies of Philebus, who are then said to be 'reputedly clever in

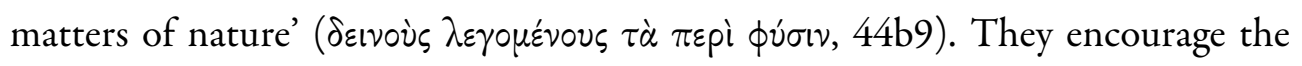
examination of something's nature ( $\phi \dot{\sigma} \sigma \mathrm{s}, 44 \mathrm{e} 1,45 \mathrm{c} 7$ ), and advise on the process of how this should be done. Even their dyschereia is linked with their not ignoble

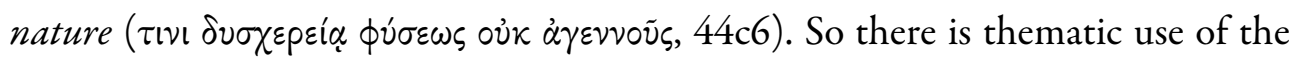

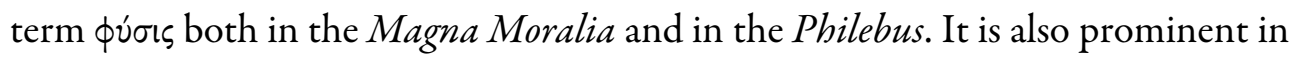
Aristotle's common-book reply to the anti-hedonists at EN 7.12 (1152b27, 34

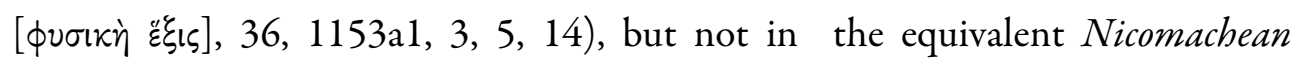
material at 10.3 .

$M M$ 2.7.13-18 considers the anti-hedonist argument that begins with the claim that not every pleasure is a good thing, since some pleasures are worthless. Similarly, it replies, there can be a worthless nature (e.g. unpleasant insects) or worthless knowledge. When we apply the anti-hedonists' own concept of pleasure, we understand how a worthless thing being restored to its own worthless nature will entail a worthless pleasure. One sees that the worthy man would for the writer experience a good pleasure, since it is a good nature to which he is being restored, whereas a poor man would only ever experience poor pleasure. This implication prepares the way for a little maliciousness, for the antihedonists are accused of failing to recognise the desirable pleasures out of inexperience! They are accused of not knowing any pleasures other than the bodily ones, identifying these ones as geneseis and unworthy of pursuit, and concluding therefore that pleasure as a whole is not a good thing. Here it should of course be noted that the Philebus does have the enemies of Philebus concentrate on the most intense pleasures, i.e. the bodily ones (45a), while there is no real indication that they would recognise non-bodily ones as pleasures at all. Further, they highlight certain base pleasures such as those of scratching an itch

18 It occurs 6 times in section 16; 3 in 10 and $13 ; 2$ in 14,15 , and 18 .

PLATO, The electronic Journal of the International Plato Society, n 8, 2008. http://gramata.univ-paris1.fr/Plato

(c) All rights of reproduction of any form reserved. 
(46a), at which they particularly sneer. Plato would agree that the 'enemies of Philebus' have overlooked very important pleasures as a result of giving prominence to physical ones, and to unattractive physical ones at that.

Here we should also draw attention to the language of 2.7.18. We have noted the unusual technical term apokatastasis in these people's concept of pleasure, and the related verb $\kappa \alpha \theta i \sigma \tau \eta \mu$ is employed to make a key distinction between types of pleasure, those belonging to the process of restoration, and those that belong to the restored state itself. The author then proclaims those that belong to the restored state superior to those involved as it is restored. Whereas EN 7.12 (1152b34-1153a3) uses the participles $\kappa \alpha \theta \iota \tau \dot{\alpha} s$ and $\kappa \alpha \theta \varepsilon \sigma \tau \eta \kappa \omega ́ s$, it fails to contrast them as directly as the $M M$ contrasts $\kappa \alpha \theta \varepsilon \sigma \tau \eta \kappa \omega ́ s$ and $\kappa \alpha \theta 1 \sigma \tau \alpha \mu \varepsilon \nu \circ \varsigma$,

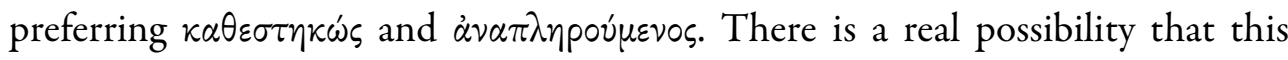
language developed in response to an anti-hedonism that emphasised the superiority of the natural state $(\kappa \alpha \tau \alpha \dot{\sigma} \eta \eta \mu \alpha)$ over processes that establish it, associating pleasure only with the latter. Both the Aristotelian response and the Epicurean one insist that the most important pleasure belongs to this natural state, and Epicurus will refer to it as catastematic pleasure. What all this suggests is that the anti-hedonists of the $M M$ are not fringe thinkers, but play a pivotal role in the development of ancient theory of pleasure. These are the anti-hedonists to whom one needs to offer a carefully argued reply.

At 2.7.19 the $M M$ proceeds to examine the idea that the good has a narrow extension while pleasure is a universal experience of animal life. If pleasure were good, then one would scarcely need to aspire to what's good. The author's response is that the very fact that all creatures can aspire to it increases the likelihood that it is the good. Little indication is offered of the reason for the claim that the good is scarce, though one might detect it in the argument that the good is determinate but pleasure is indeterminate (EN 10.3, 1173a15-25), and (like the apeiron of the Philebus, 25c) admits of the 'more and less'. While this is

PLATO, The electronic Journal of the International Plato Society, n 8, 2008. http://gramata.univ-paris1.fr/Plato

(c) All rights of reproduction of any form reserved. 
far from certain, one should remember the enigmatic words of Theophrastus when referring to Speusippus' notion that the good was something scarce, occupying the centre ground, while evil was to be found on both sides and not in indeterminacy alone $($ F83 = 71 I-P). Certainly indeterminacy, which Speusippus must surely have associated with pleasures and pains, was part of his reason for his refusing to regard either as good. But none of this yet relates directly to the enemies of the Philebus, unless perhaps one may point to the strong link made by Aristotle at $E N 10.3$ (1173a22-23) between the alleged indeterminacy of pleasure and the notion that it is habitually mixed with pain. ${ }^{19}$

In section 21 the $M M$ moves to consider the argument that pleasure is a hindrance to virtuous conduct. The argument goes back at least to the Phaedo, which talked of the nails that both pains and pleasures hammered into the soul, forcing it to agree mistakenly to the reality of the body (83d), while the Philebus continues to present bodily pleasures as hindrances to intellectual activity (63d). The impediment argument as presented at EN 7.11 (1152b17-18) emphasises that sexual activity is an intellectual impediment. Yet in the summary of arguments in the $M M$ this argument was that pleasure impeded moral ( $\tau \dot{\alpha} \kappa \alpha \lambda \dot{\alpha})$ rather than intellectual virtue (1204b2-3). In the author's reply, however, the impediment argument seems to have both an intellectual and a moral element. Hence it is maintained at 2.7.22 that one type of knowledge can be a hindrance to another, while at 2.7.23-25 we learn that a good man should be getting pleasure from his morally virtuous deeds.

Section 26 replies to the Gorgias-inspired objection (absent from the MSS at 2.7.3) that there is no craft producing pleasure, whereas there would be if pleasure

19 According to my reading, Aristotle believes the existence of unmixed pleasures refutes the view in question; anti-hedonists see pleasures and pains as usually understood as partners in a mixture that permits much variation in proportion, but pure pleasure would no longer be somewhere on a scale of more or less pleasant, being positioned at a fixed point at one end of the scale.

PLATO, The electronic Journal of the International Plato Society, n 8, 2008.

http://gramata.univ-paris1.fr/Plato

(c) All rights of reproduction of any form reserved. 
and the good were identical, while 27 responds to our argument $3 \mathrm{c}$ that pleasure is not best, while the good is best. How this argument could be understood as an argument against pleasure being good in some meaningful sense is unclear, and indeed it was unclear to the author as well, who thinks that absurdities will follow when it is realised that no single virtue can be best in its own right either. The response to these later arguments do not contain the same distinctive language that we have noted at 2.7.4-18, and does little to flesh out the picture of the $M M$ 's anti-hedonists.

\section{iv. What is missing in the MM?}

Just as Schofield found strong linguistic arguments for identifying Plato's dyschereis with Speusippus, so there are strong linguistic arguments for identifying the MM's dyschereis with Plato's! Yet key elements of the Platonic passage are absent from the $M M$, primarily the denial that pleasure exists, but also the apparent link with false pleasures and the special connection with pleasures that are mixed with pains. This last is unproblematic, since the theme of mixed pleasures is never turned into an effective anti-hedonist argument, and is not treated as such in the Nicomachean Ethics. Nor for that matter is the theme of false pleasures, for no amount of criticism of what is falsely called pleasure would count against the identification of (real) pleasure as a good. Thus one key question remains: how the $M M$ could omit the anti-hedonist denial that any genuine pleasure exists at all if it is alluding to Plato's dyschereis.

Here the answer should begin with observation of a difference between all Aristotelian accounts of the genesis argument and Plato's. Plato alone opposes the term genesis to ousia, implying that the two terms are exclusive, even though one may lead to the other. In Aristotle genesis leads rather to an end or telos, as may be

PLATO, The electronic Journal of the International Plato Society, n 8, 2008. 
seen from his early use of the genesis theme in the ethics of the Protrepticus, ${ }^{20}$ as well as from EN 1152b14 and 153a7-12. In the anti-hedonists it leads rather to a physis (EN 1152b13). The use of the term ousia for stable reality is therefore (unsurprisingly) Plato's. Plato himself had likewise called into question the reality or truth of everyday pleasure in the Republic (583b, 585b-d). He had never believed that no pleasure was real or true, and he still does not believe that in the Philebus. But the Plato of the Republic would have held that no pleasure was real or true if (a) there were no pleasures more real than those of the common man, while (b) the common man experienced nothing pleasanter than freedom from pain. For him, denying that there was anything pleasanter than freedom from pain (which cannot really be pleasure itself) would have been to deny that any pleasure was real. The dyschereis_insist on examining the nature of pleasure from its intense cases, thus overlooking the subtle pleasures that Plato would call 'real' and imagining that all pleasures, when correctly assessed, would be less pleasant than the pain-free condition. But the pain-free condition is not a true pleasure, and therefore anything less pleasant than the pain-free condition cannot truly be pleasure either. Thus there would be no true pleasure at all. All pleasure is fooling us.

Hence Plato is not trying to represent the 'enemies of Philebus' on their own terms, but drawing out the implications of what he understands their position to be. The result of accepting most of his analysis in Republic IX and refusing to accept that there are superior pleasures will be to deny the reality of any pleasure one cares to name. They may be prepared to accept this consequence, but the intention of their position is not to show the non-reality of pleasure but to show its inferiority and its incompatibility with the best life. And I strongly suspect that Plato's representation of their position is not entirely satire-free. It is precisely because he intends to depict their position in his own terms that he needs to offer clues that will serve to identify whom he has in mind. The author

20 Iambl. Protr. 9, 79.25-80.4, 81.21-3 des Places.

PLATO, The electronic Journal of the International Plato Society, n 8, 2008. http://gramata.univ-paris1.fr/Plato

(c) All rights of reproduction of any form reserved. 
of the $M M$ was well able to recognise these clues, and to depict the dyschereis in more appropriate terms.

\section{v. Conclusions}

The arguments for the identity of Plato's 'Friends of Philebus' and the antihedonists of MM 2.7 are as strong as any that we should be entitled to expect in cases like this. Both works appear to be making use of the same type of antihedonist language. However, if this identity-thesis is accepted it suggests also that these 'Friends of Philebus' has a wider influence over the arguments and language of the Philebus than is normally supposed. The fact that a number of linguistic oddities are shared with fragments of Speusippus would appear to strengthen if not actually confirm the case for identifying Speusippus as the principle $d y s c h e r e \hat{s}$ and the main anti-hedonist opponent in both works, though Plato's usual enigmatic (and somewhat ironic) treatment is often in danger of obscuring this.

Strangely, the discussion of pleasure in the Aristotelian work seems closer linguistically to the world of the Philebus than anything in either of the undisputedly genuine accounts of the debate on pleasure in the Nicomachean Ethics. In view of the tendency of the $M M$ to resemble the Eudemian rather than Nicomachean Ethics, it is not unexpected that 7.2 resembles the Common Book (and hence perhaps Eudemian) account in VII rather than the exclusively Nicomachean account in X. This cannot on its own tell us very much about the work as a whole, or of its date. What it does strongly suggest is that the discussion of pleasure is adapted from an early Aristotelian account, perhaps written in the 340s while Speusippus was still alive, when it suited Aristotle to be able to engage with him at a more personal level by imitating Speusippean language. The extent to which other parts of the $M M$ might be based on early Aristotle, with revisions and/or additions, is regrettably beyond the scope of the present study. It is, however, an issue that one should like to see studied sooner rather than later, and

PLATO, The electronic Journal of the International Plato Society, n 8, 2008.

http://gramata.univ-paris1.fr/Plato

(c) All rights of reproduction of any form reserved. 
with reference to the degree that it appears to reflect the specialist language and interests of the Academy towards the end of Plato's life.

Harold Tarrant

University of Newcastle, Australia

PLATO, The electronic Journal of the International Plato Society, n 8, 2008. http://gramata.univ-paris1.fr/Plato

(c) All rights of reproduction of any form reserved. 